А. Н. Макаров, В. С. Потаев, Г. Ю. Субанаков. Исследование закономерностей и условий функционирования и развития наставничества в региональной системе образования

Научная статья

УДК 332.145

DOI: $10.18101 / 2304-4446-2021-2-43-54$

\title{
ИССЛЕДОВАНИЕ ЗАКОНОМЕРНОСТЕЙ И УСЛОВИЙ ФУНКЦИОНИРОВАНИЯ И РАЗВИТИЯ НАСТАВНИЧЕСТВА В РЕГИОНАЛЬНОЙ СИСТЕМЕ ОБРАЗОВАНИЯ
}

\author{
(C) Макаров Александр Николаевич \\ кандидат физико-математических наук, доцент \\ an-makarov2008@yandex.ru
}

\section{(C) Потаев Виктор Сергеевич}

доктор экономических наук, профессор

potaev_viktor@mail.ru

\section{(C) Субанаков Георгий Юрьевич}

кандидат экономических наук

subgeorge@mail.ru

Бурятский государственный университет имени Доржи Банзарова

Россия, 670000, г. Улан-Удэ, ул. Смолина 24а

В статье приводятся особенности и эффективность внедрения наставничества в высших учебных заведениях. На основе анализа учебной, учебно-методической, научной и воспитательной деятельности в Бурятском государственном университете разработаны порядок и схема внедрения системы наставничества. Исходя из особенностей вузовской деятельности, предлагаемая система предполагает создание нескольких форм наставничества: наставник-куратор, наставник-научный руководитель, наставник-студент (старшекурсник), наставник-производственник. Соответственно предлагаются модели наставничества: 1) от школы к вузу; 2) от вуза к производству; 3) от производства к карьере. Благодаря наставничеству предполагается повысить посещаемость занятий студентами, их текущую успеваемость, улучшить защиту выпускных квалификационных работ и трудоустройство. Наставничество должно помочь частично или полностью избавиться от таких проблем современной высшей школы, как низкая мотивация к учебе и саморазвитию, дисциплинарные затруднения, неудовлетворительная успеваемость, отсутствие у студентов качественной саморегуляции, низкая информированность о карьерных и образовательных возможностях, отсутствие осознанного выбора пути будущего карьерного роста, трудности, связанные с невозможностью совмещать получение образования и работу, низкий уровень общей культуры, неразвитость метакомпетенций.

Ключевые слова: наставничество, особенности, высшее образование, компетенции, мягкие навыки, кураторы, менторы, эффективность

\section{Для цитирования}

Макаров А. Н., Потаев В. С., Субанаков Г. Ю. Исследование закономерностей и условий функционирования и развития наставничества в региональной системе образования // Вестник Бурятского государственного университета. Экономика и менеджмент. 2021. № 2. С. 43-54. 
Как известно, система образования в Российской Федерации состоит из дошкольного, среднего общего и профессионального, высшего уровней образования. На всех уровнях образования в той или иной мере присутствует наставничество как со стороны родителей, семьи, родственников, друзей, учителей, преподавателей, одноклассников, однокурсников и других. В процессе формирования личности часто наставничество является одним из основных его факторов. В зависимости от того, с кем человек с детства больше общался, больше проводил время и в какой социокультурной среде он рос, как все это влияло на него, зависит его будущий личностный успех. Роль наставничества настолько важная, что она отражена в Указе Президента РФ «Наставничество - цель развития нашей системы и один из инструментов достижения конкурентоспособности страны в целом и ее системы образования» ${ }^{1}$.

Поэтому необходимость внедрения наставничества в высших учебных заведениях среди студенчества не вызывает сомнения. В связи с этим нами была поставлена цель: изучить его особенности и эффективность внедрения системы наставничества в вузах на примере ФГБОУ ВО «Бурятский государственный университет имени Доржи Банзарова» (далее - БГУ).

Информационную базу исследований составили нормативно-правовые и законодательные акты Российской Федерации и Республики Бурятия, касающиеся темы исследований, научная литература, данные Бурятского государственного университета имени Доржи Банзарова, учебно-методические и другие материалы, используемые на кафедрах университета.

Так, БГУ видит свою миссию в обеспечении реализации государственной политики России путем организации инновационной научно-образовательной системы подготовки конкурентоспособных кадров нового поколения и научных знаний, воплощенных в технико-технологические, организационноуправленческие и социокультурные решения. В своей деятельности университет руководствуется Конституцией Российской Федерации от 12.12 .1993 с изменениями от 01.07.2020², Федеральным законом от 29 декабря 2012 г. № 273-Ф3 «Об образовании в Российской Федерации» ${ }^{3}$, Государственной программой развития образования на 2018-2025 гг., утвержденной постановлением Правительства Российской Федерации от 26.12.2017 №16424, Уставом ФГБОУ ВО «Бурятский государственный университет имени Доржи Банзарова», утвержденным приказом Министерства науки и высшего образования РФ от 27.12.2018 г. №1294 и другими документами 5 .

При анализе первичных источников отдельного документа в БГУ о наставничестве, его роли, положения о наставниках и наставляемых, их работе, не обна-

\footnotetext{
${ }^{1} \mathrm{O}$ профессиональном развитии государственных гражданских служащих Российской Федерации: указ Президента РФ от 21.02.2019 № 68.

${ }^{2}$ Конституция Российской Федерации от 12.12.1993 г., с изменениями от 01.07.2020.

${ }^{3}$ Об образовании в Российской Федерации: федеральный закон от 29 декабря 2012 г. № 273-Ф3.

${ }^{4}$ Государственная программа РФ «Развитие образования» на 2018-2025 гг.: утверждена постановлением Правительства РФ от 26.12.2017 № 1642.

5 Устав ФГБОУ ВО «Бурятский государственный университет имени Доржи Банзарова»: утвержден приказом Министерства науки и высшего образования РФ от 27.12.2018 г. № 1294.
} 
А. Н. Макаров, В. С. Потаев, Г. Ю. Субанаков. Исследование закономерностей и условий функционирования и развития наставничества в региональной системе образования

ружено. Примерно такая же картина наблюдается во многих других вузах России. Однако наставничество в университете присутствовало и присутствует всегда, в первую очередь оно выражается в сотрудничестве профессорскопреподавательского состава и студенчества во время учебных занятий и во внеучебное время. Преподаватели своим поведением, отношением к окружающим, событиям, профессионализмом, эрудицией, самодисциплиной, творчеством и многим другим являются примером для студентов. Они вызывают желание у молодых людей формировать подобные черты характера и компетенции у себя.

Упрощенная карта производственного процесса в Бурятском государственном университете на очной форме обучения выглядит следующим образом:

Ha входе: абитуриенты в лице выпускников школ и колледжей, поступившие на первый курс обучения в Бурятский государственный университет по выбранному направлению.

Процессы/операции преобразования: обучение студентов и формирование у них универсальных, общепрофессиональных и профессиональных компетенций во время их аудиторных и самостоятельных занятий. К основным операциям по преобразованию студентов со стороны преподавателей относятся чтение лекций, проведение практических занятий, обеспечение студентов учебно-методической литературой, материалами и заданиями для их самостоятельной работы, консультирование, контроль и мотивация студентов в процессе обучения, закрепления знаний и навыков во время прохождения производственной практики и выполнения выпускных квалификационных работ.

Ha выходе: выпускники университета, освоившие программу бакалавриата или магистратуры, обладающие необходимыми компетенциями для выполнения соответствующей профессиональной деятельности.

Ключевой проблемой в процессе подготовки будущих профессионалов в университете является слабое формирование у студентов за время учебы «мягких навыков» (soft skills). Твердые навыки (hard skills) формируются в целом у студентов очень неплохо. Однако без умения ставить цели и доводить начатое дело до конца, настоять на принятом решении и противостоять чужому влиянию, брать на себя ответственность, руководить и других soft skills многие выпускники вузов остаются без работы, карьерного роста, без собственного бизнеса и т. д.

Для устранения данного недостатка, его нивелирования, лучшего развития soft skills в нами предлагается внедрение системы наставничества, которая способна формировать у студентов «мягкие» навыки», что, несомненно, будет содействовать более эффективному процессу обучения, трудоустройству выпускников Бурятского государственного университета. В предлагаемой нами системе наставничества оно будет осуществляться как индивидуально, так и в группах. В работе со студентами будут использоваться такие методы, как интерактивные беседы, диалоги, дискуссии, консультации, инструктирование, демонстрация действий и поведения в виде мастер-классов, «научение через наблюдение», бизнес-тренинги, коучинговые сессии, персонализированная имитация, анализ практических ситуаций, рефлексия и анализ деятельности подопечного и др.

В настоящее время основными звеньями организации и управления воспитательной деятельностью на уровне институтов и факультетов в БГУ являются заместители деканов факультетов и заместители директоров институтов по воспитанию. На уровне кафедр непосредственно учебно-воспитательной работой за- 
нимаются кураторы академических групп и преподаватели во время своих лекций, занятий и других контактов со студентами.

Учитывая особенности подготовки кадров в Бурятском государственном университете, нами разработана матрица распределения задач при внедрении системы наставничества (табл. 1).

Таблица 1

Матрица распределения административных задач при внедрении системы наставничества

\begin{tabular}{|c|c|c|c|c|c|c|}
\hline & \multirow{2}{*}{$\begin{array}{l}\text { Директор, } \\
\text { декан }\end{array}$} & \multicolumn{3}{|c|}{ Ответственный за } & \multirow{2}{*}{$\begin{array}{l}\text { Кура- } \\
\text { торы }\end{array}$} & \multirow{2}{*}{$\begin{array}{l}\text { Руководи- } \\
\text { тели ВкР }\end{array}$} \\
\hline & & УМP & УВР & HP & & \\
\hline $\begin{array}{l}\text { Разработка проекта } \\
\text { внедрения системы } \\
\text { наставничества }\end{array}$ & Д & $\mathrm{O}$ & $\mathrm{O}$ & 0 & $\mathrm{O}$ & C \\
\hline $\begin{array}{l}\text { Согласование с руковод- } \\
\text { ством института и уни- } \\
\text { верситета }\end{array}$ & Д & $\mathrm{O}$ & $\mathrm{O}$ & 0 & C & C \\
\hline $\begin{array}{l}\text { Ознакомление студен- } \\
\text { тов с системой настав- } \\
\text { ничества }\end{array}$ & K & K & K & K & и & и \\
\hline $\begin{array}{l}\text { Внедрение системы } \\
\text { наставничества }\end{array}$ & K & K & K & K & и & и \\
\hline $\begin{array}{l}\text { Выявление и устранение } \\
\text { недостатков системы } \\
\text { наставничества }\end{array}$ & K & K & K & K & и & и \\
\hline
\end{tabular}

где: Д - единоличное принятие решения; $\mathrm{O}$ - обсуждение; $\mathrm{C}$ - согласование; И исполнение; К — контроль.

На основании матрицы распределения административных задач при внедрении системы наставничества разработана диаграмма Ганта (табл. 2).

Таблица 2

Диаграмма Ганта внедрения системы наставничества

\begin{tabular}{|l|l|l|l|l|l|}
\hline & \multicolumn{3}{|c|}{2021 г. } & 2022 г. \\
\cline { 2 - 6 } & 20.04 & 20.09 & 20.10 & 20.12 & 20.02 \\
\hline $\begin{array}{l}\text { Разработка проекта внедре- } \\
\text { ния системы наставничества }\end{array}$ & & & & & \\
\hline $\begin{array}{l}\text { Согласование с руководством } \\
\text { института и университета }\end{array}$ & & & & & \\
\hline $\begin{array}{l}\text { Ознакомление студентов с } \\
\text { системой наставничества }\end{array}$ & & & & & \\
\hline $\begin{array}{l}\text { Внедрение системы настав- } \\
\text { ничества }\end{array}$ & & & & & \\
\hline $\begin{array}{l}\text { Выявление и устранение не- } \\
\text { достатков системы наставни- } \\
\text { чества }\end{array}$ & & & & & \\
\hline
\end{tabular}


А. Н. Макаров, В. С. Потаев, Г. Ю. Субанаков. Исследование закономерностей и условий функционирования и развития наставничества в региональной системе образования

Основным документом в проекте внедрения системы наставничества в университете будет «Положение о наставничестве студентов БГУ», которое будет включать в себя положения о наставниках в Бурятском государственном университете. Данные документы согласно представленной диаграмме Ганта будут разработаны до 20 сентября 2021 г. После обсуждения и принятия их на заседании кафедрах они будут согласовываться с руководством институтов, факультетов и университета (до 20.10.2021). Документами, подтверждающими прохождение данных этапов внедрения, будут: 1) решение заседания кафедр; 2) решения Ученого совета института и факультетов; 3) решение учебно-методического совета Бурятского государственного университета об утверждении «Положения о наставничестве студентов БГУ» и положения о наставниках.

Этап «Ознакомление студентов с системой наставничества» будет включать в себя вначале согласование и одобрение положения и программы со студенческим советом университета, затем широкое обсуждение среди студентов и одобрение этих и, возможно других локальных документов студенчеством университета.

Внедрение системы наставничества в БГУ будет выполняться главным образом на уровне его первичных подразделений, кафедрах. Например, на кафедрах может быть следующее дополнительное распределение обязанностей наставников (табл. 3).

Таблица 3

Распределение наставничества среди ППС

\begin{tabular}{|c|c|c|c|}
\hline $\begin{array}{c}\text { Форма } \\
\text { наставничества }\end{array}$ & Содержание наставничества & Наставник (и) & $\begin{array}{c}\text { Наставляемый } \\
\text { (ые) }\end{array}$ \\
\hline \multicolumn{4}{|c|}{ Бакалавриат } \\
\hline $\begin{array}{l}\text { Куратор- } \\
\text { наставник }\end{array}$ & $\begin{array}{l}\text { Адаптация студентов 1-го и 2-го } \\
\text { курса к учебно-воспитательному } \\
\text { процессу университета. Помощь } \\
\text { студентам 3-го и 4-го курса завер- } \\
\text { шить учебу и защитить ВКР }\end{array}$ & Кураторы & $\begin{array}{l}\text { Студенты 1-4 } \\
\text { курсов }\end{array}$ \\
\hline $\begin{array}{l}\text { Научный руко- } \\
\text { водитель- } \\
\text { наставник }\end{array}$ & $\begin{array}{l}\text { Оказание поддержки и помощи } \\
\text { студентам в выборе будущего ме- } \\
\text { ста работы, карьерного роста и т. п. }\end{array}$ & $\begin{array}{l}\text { Все преподава- } \\
\text { тели кафедры }\end{array}$ & $\begin{array}{l}\text { Студенты 3-4 } \\
\text { курсов }\end{array}$ \\
\hline \multicolumn{4}{|c|}{ Магистратура } \\
\hline $\begin{array}{l}\text { Куратор- } \\
\text { наставник }\end{array}$ & $\begin{array}{l}\text { Помощь студентам магистратуры } \\
\text { определиться с темой, выполнить и } \\
\text { защитить ВКР }\end{array}$ & Кураторы & $\begin{array}{l}\text { Студенты 1-2 } \\
\text { курсов }\end{array}$ \\
\hline $\begin{array}{l}\text { Научный руко- } \\
\text { водитель- } \\
\text { наставник }\end{array}$ & $\begin{array}{l}\text { Оказание поддержки и помощи } \\
\text { студентам в выборе будущего ме- } \\
\text { ста работы, карьерного роста и т. п. }\end{array}$ & $\begin{array}{l}\text { Все остепе- } \\
\text { ненные препо- } \\
\text { даватели ка- } \\
\text { федры }\end{array}$ & $\begin{array}{l}\text { Студенты 1-2 } \\
\text { курсов }\end{array}$ \\
\hline \multicolumn{4}{|c|}{ Аспирантура } \\
\hline $\begin{array}{l}\text { Научный руко- } \\
\text { водитель- } \\
\text { наставник }\end{array}$ & $\begin{array}{l}\text { Оказание поддержки и помощи } \\
\text { студентам в выборе будущего ме- } \\
\text { ста работы, карьерного роста и т. п. }\end{array}$ & $\begin{array}{l}\text { Профессора } \\
\text { кафедры }\end{array}$ & Аспиранты \\
\hline
\end{tabular}


Как видно из таблицы 3, роли кураторов-наставников и кураторов научных руководителей по содержанию будут отличаться друг от друга. Главной задачей куратора студентов первого и даже второго курсов будет помощь первокурсникам в адаптации к новым условиям обучения, отличным от школьных. Известно что, несмотря на схожесть учебных процессов в школе и вузе, они отличаются друг от друга. Если до университета школьник чувствовал на себе тотальный контроль всего учебного процесса, образования и воспитания как со стороны школы, так и со стороны родителей, то в вузе он представлен практически самому себе. Однако кажущаяся свобода для многих первокурсников становится проблемой, лишившись тотального контроля они не знают, что делать с этой «свободой», не умеют распределять свое время и управлять им. Здесь могут помочь новому адепту кураторы-наставники и студенты старшекурсники.

Наставничество студентов-первокурсников со стороны студентовстаршекурсников можно назвать «баддингом» (от англ. buddy - приятель). К баддиндгу можно отнести также влияние на студента со стороны представителей студенческого самоуправления, профкома, «старостата» и т. п.

Для научных руководителей-наставников в университете основными учебнометодическими пособиями являются «Программы государственной итоговой аттестации», «Методические указания для обучающихся по прохождению производственной практики», «Методические указания для обучающихся по прохождению преддипломной практики» и «Методические рекомендации по выполнению и подготовке к защите выпускной квалификационной работы».

Основные необходимые формальные требования к наставнику в зависимости от того, кем он является, представлены в таблице 4.

Таблица 4

Необходимые требования к наставнику и модели наставничества

\begin{tabular}{|c|c|c|c|c|}
\hline & $\begin{array}{c}\text { Наставник- } \\
\text { куратор }\end{array}$ & $\begin{array}{c}\text { Наставник- } \\
\text { научный } \\
\text { руководитель }\end{array}$ & $\begin{array}{c}\text { Наставник- } \\
\text { студент } \\
\text { (старшекурс- } \\
\text { ник) }\end{array}$ & $\begin{array}{c}\text { Наставник } \\
\text { на производстве } \\
\text { (специалист, } \\
\text { руководитель, } \\
\text { предпринима- } \\
\text { тель) }\end{array}$ \\
\hline $\begin{array}{l}\text { Основное об- } \\
\text { разование }\end{array}$ & высшее & $\begin{array}{l}\text { высшее, } \\
\text { канд. наук, } \\
\text { д-р наук }\end{array}$ & $\begin{array}{l}\text { незаконченное } \\
\text { высшее }\end{array}$ & высшее \\
\hline Стаж работы & $\begin{array}{l}\text { не менее } \\
1 \text { года }\end{array}$ & не менее 5 лет & $\begin{array}{l}\text { 3-4 курс обу- } \\
\text { чения }\end{array}$ & не менее 5 лет \\
\hline $\begin{array}{l}\text { Дополнитель- } \\
\text { ное образова- } \\
\text { ние }\end{array}$ & $\begin{array}{l}\text { педагогическое, } \\
\text { психологиче- } \\
\text { ское }\end{array}$ & $\begin{array}{l}\text { педагогиче- } \\
\text { ское, } \\
\text { психологиче- } \\
\text { ское }\end{array}$ & - & $\begin{array}{l}\text { наставничество, } \\
\text { коучинг, } \\
\text { бизнес-тренинг }\end{array}$ \\
\hline $\begin{array}{l}\text { Модель } \\
\text { наставничества }\end{array}$ & $\begin{array}{l}\text { от школы к вузу } \\
\text { от вуза к произ- } \\
\text { водству }\end{array}$ & $\begin{array}{l}\text { от вуза } \\
\text { к производству }\end{array}$ & $\begin{array}{l}\text { от школы к } \\
\text { вузу }\end{array}$ & $\begin{array}{l}\text { от вуза к произ- } \\
\text { водству } \\
\text { от производства } \\
\text { к карьере }\end{array}$ \\
\hline
\end{tabular}


А. Н. Макаров, В. С. Потаев, Г. Ю. Субанаков. Исследование закономерностей и условий функционирования и развития наставничества в региональной системе образования

Особенности работы наставника с наставляемым, как видно из таблицы 4, будут зависеть от используемой модели наставничества. Так, наставник-куратор, работающий по модели «от школы к вузу», главное внимание в своей работе уделяет адаптации вчерашнего школьника к университетской системе обучения. В это же время к этой модели наставничества должны подключаться наставникистуденты. Это, как правило, старшекурсники из студенческого самоуправления. Отношения старшекурсников с первокурсниками - это больше, чем «баддинг».

Модель наставничества «от вуза к производству» наиболее ярко будет проявляться во время прохождения студентами производственной и преддипломной практики. В данный период времени от университета наставником будет руководитель производственной и преддипломной практики, а на производстве - pyководитель практики от организации (предприятия). В дальнейшем последний может стать наставником в модели «от производства к карьере».

Независимо от модели наставничества, от того, кто выполняет роль наставника к необходимым качествам наставника должны относиться:

1) желание поддержать другого человека в течение длительного времени;

2) уважение к человеку, его способностям и праву делать свой собственный выбор в учебе, работе, жизни;

3) умение слушать и принимать различные точки зрения;

4) умение сопереживать другому человеку, видеть его проблемы и способы решения;

5) гибкость и критичность мышления, открытость в отношениях с наставляемым;

6) толерантность и эмпатия;

7) рефлексивность и эмоциональная устойчивость.

Примерную схему наставничества можно представить следующим образом:

\begin{tabular}{|c|c|c|}
\hline Наставник-куратор & $\begin{array}{c}\text { Наставник-научный } \\
\text { руководитель }\end{array}$ & $\begin{array}{c}\text { Наставник-студент } \\
\text { (старшекурсник) }\end{array}$ \\
\hline \multicolumn{3}{|c|}{ Студент-первокурсник БГУ } \\
\hline $\begin{array}{l}\text { Групповое наставничество } \\
\text { 10-15 чел. }\end{array}$ & \multirow[t]{2}{*}{$\begin{array}{c}\text { Индивидуальное наставни- } \\
\text { чество 3-4 чел. }\end{array}$} & $\begin{array}{l}\text { Групповое наставничество } \\
\text { 10-15 чел. }\end{array}$ \\
\hline $\begin{array}{l}\text { Индивидуальное наставни- } \\
\text { чество 1-2 чел. } \\
\text { по мере необходимости }\end{array}$ & & $\begin{array}{l}\text { ИндивИдуальное наставни- } \\
\text { чество 1-2 чел. } \\
\text { по мере необходимости }\end{array}$ \\
\hline $\begin{array}{r}\text { Индиви } \\
\text { (специ }\end{array}$ & $\begin{array}{l}\text { 1ьное наставничество на прс } \\
\text { ст, руководитель, предприн }\end{array}$ & $\begin{array}{l}\text { зводстве } \\
\text { иатель) }\end{array}$ \\
\hline
\end{tabular}

Рис. 1. Примерна схема непрерывного наставничества

Групповое наставничество подразумевает работу одного преподавателя или студента-старшекурсника с академической группой (обычно 10-15 чел.). Преподаватель или студент в роли лидера регулярно проводит встречи с курируемой 
группой на протяжении длительного периода. Наставник-куратор встречается с группой на протяжении всего периода обучения, наставник-студент — на 1-2-х курсах обучения. Тем не менее они занимаются индивидуальным наставничеством по мере необходимости.

Наставник-научный руководитель будет подключаться к наставничеству с 3-го курса обучения студента наставляемого (менти), после распределения студентов по руководителям производственной практики, а затем и преддипломной практики. В его обязанности также должна входить помощь студентувыпускнику в трудоустройстве или открытии собственного дела.

После сдачи государственного экзамена и защиты выпускной квалификационной работы студент-выпускник переходит уже в наставнические руки производственников. Ими как правило являются специалисты предприятия, например, какой-нибудь экономист, руководитель подразделения куда он попал, директор или хозяин бизнеса, если предприятие будет небольшим.

В завершении необходимых качеств наставника можно добавить определение наставника, которое дает К. Крэм [6]. Он определяет наставника как человека с передовым опытом и знаниями, которому поручено обеспечение вертикальной мобильности и поддержки в процессе карьеры своим протеже. Он должен поддерживать молодого человека, вести и консультировать его, научить «плавать во взрослом мире и мире учебы и работы».

Эффективность внедрения системы наставничества, на наш взгляд, можно рассматривать в первую очередь по объективным показателям, которые используются в Бурятском государственном университете имени Доржи Банзарова. К ним относятся посещаемость занятий студентами, текущая их успеваемость, сдача государственных экзаменов и результаты защиты выпускных квалификационных работ [3-5].

В таблице 5 представлены текущие показатели, показатели на следующий год после внедрения наставничества и эталонные значения.

Таблица 5

Текущие показатели эффективности учебного процесса и на перспективу

\begin{tabular}{|c|c|c|c|}
\hline & $\begin{array}{c}\text { Текущий уровень } \\
\text { показателя }\end{array}$ & $\begin{array}{c}\text { Значение } \\
\text { показателя на сле- } \\
\text { дующий год }\end{array}$ & $\begin{array}{c}\text { Эталонное значение } \\
\text { показателя }\end{array}$ \\
\hline $\begin{array}{l}\text { Посещаемость заня- } \\
\text { тий студентами }\end{array}$ & $\begin{array}{l}80 \% \text { студентов из } \\
\text { общего числа не } \\
\text { имеют пропусков } \\
\text { занятий }\end{array}$ & $\begin{array}{l}\text { 90\% студентов из } \\
\text { общего числа не } \\
\text { имеют пропусков } \\
\text { занятий }\end{array}$ & $\begin{array}{l}\text { 100\% посещение } \\
\text { занятий }\end{array}$ \\
\hline $\begin{array}{l}\text { Текущая успевае- } \\
\text { мость студентов }\end{array}$ & в среднем 4,5 балла & в среднем 4,7 балла & в среднем 5 баллов \\
\hline $\begin{array}{l}\text { Сдача государствен- } \\
\text { ных экзаменов }\end{array}$ & в среднем 4,6 балла & в среднем 4,8 балла & в среднем 5 баллов \\
\hline $\begin{array}{l}\text { Защита выпускных } \\
\text { квалификационных } \\
\text { работ }\end{array}$ & в среднем 4,6 балла & в среднем 4,8 балла & в среднем 5 баллов \\
\hline Трудоустройство & $\begin{array}{l}60 \% \text { трудоустрой- } \\
\text { ство }\end{array}$ & $\begin{array}{l}\text { 80\% трудоустрой- } \\
\text { ство }\end{array}$ & $\begin{array}{l}100 \% \text { трудоустрой- } \\
\text { ство }\end{array}$ \\
\hline
\end{tabular}


А. Н. Макаров, В. С. Потаев, Г. Ю. Субанаков. Исследование закономерностей и условий функционирования и развития наставничества в региональной системе образования

Текущие показатели эффективности учебного процесса в Бурятском государственном университете, как видно из таблицы 5 , в целом удовлетворительные. $80 \%$ студентов из общего числа не имеют пропусков занятий, средняя оценка по итогам текущих экзаменационных сессий составляет 4,5 балла, сдачи государственного экзамена и защиты ВКР - 4,6 балла. После окончания вуза примерно $60 \%$ выпускников трудоустраиваются. В последующем при внедрении системы наставничества показатели эффективности учебы на кафедре, по нашим предположениям, должны значительно улучшиться.

Наставничество по результатам его внедрения и мнения многих экспертов поможет частично или полностью избавиться от таких проблем современной высшей школы, как низкая мотивация к учебе и саморазвитию, дисциплинарные затруднения, неудовлетворительная успеваемость, отсутствие у студентов качественной саморегуляции, низкая информированность о карьерных и образовательных возможностях, отсутствие осознанного выбора пути будущего карьерного роста, трудности, связанные с невозможностью совмещать получение образования и работу, низкий уровень общей культуры, неразвитость метакомпетенций, в основном целеполагания, планирования и навыков самореализации, пессимистические ожидания. Невозможность реализовать свой предпринимательский или профессиональный потенциал в силу отсутствия опыта и ресурсов.

Внедрение системы наставничества в университетах будет эффективной и полезной не только для обучающихся студентов, но и для всех его участников (табл. 6).

Эффективность внедрения системы наставничества подтверждается также его историей и данными экспертов. Первым наставником был мифический герой Древней Греции Ментор, друг Одиссея. Он отдал своего сына Телемаха на воспитание Одиссею и попросил его научить сына всему, что он умеет. Следовательно, уже тогда знали об эффективности наставничества. В системе общего и профессионального образования оно на первых порах появилось в виде тьютерства. В высшей школе впервые тьютерство как форму наставничества начали использовать в первых британских университетах, таких как Оксфордский и Кембриджский. В настоящее время в ведущих вузах мира наставничество развивается под названием «менторство».

Таблица 6

Эффективность внедрения системы наставничества в БГУ

\begin{tabular}{|c|c|c|c|c|c|}
\hline \multicolumn{2}{|c|}{$\begin{array}{c}\text { Для студентов - } \\
\text { менти }\end{array}$} & \multirow{2}{*}{$\begin{array}{c}\text { Для } \\
\text { студентов - } \\
\text { менторов } \\
\text { 3-4-х курсов } \\
\text { обучения }\end{array}$} & \multicolumn{2}{|c|}{$\begin{array}{c}\text { Для преподавателей - } \\
\text { менторов }\end{array}$} & \multirow{2}{*}{$\begin{array}{c}\text { Для } \\
\text { производ- } \\
\text { ственника- } \\
\text { ментора }\end{array}$} \\
\hline $\begin{array}{c}\text { 1-2-х курсов } \\
\text { обучения }\end{array}$ & $\begin{array}{c}\text { 3-4-х кур- } \\
\text { сов обуче- } \\
\text { ния }\end{array}$ & & оров & $\begin{array}{c}\text { научных } \\
\text { руко- } \\
\text { водителей }\end{array}$ & \\
\hline $\begin{array}{l}\text { В условиях } \\
\text { отрыва от } \\
\text { дома и ро- } \\
\text { дителей } \\
\text { первокурс- }\end{array}$ & $\begin{array}{l}\text { Комплекс- } \\
\text { ное осво- } \\
\text { ение сту- } \\
\text { дентами } \\
\text { всех видов }\end{array}$ & $\begin{array}{l}\text { Студент- } \\
\text { старше- } \\
\text { курсник в } \\
\text { лице сту- } \\
\text { дентов- }\end{array}$ & $\begin{array}{l}\text { Выполне- } \\
\text { ние функ- } \\
\text { ций кура- } \\
\text { тора- } \\
\text { наставника }\end{array}$ & $\begin{array}{l}\text { Повышает } \\
\text { репутацию и } \\
\text { доверие } \\
\text { коллег, раз- } \\
\text { вивает }\end{array}$ & $\begin{array}{l}\text { Возможность } \\
\text { передачи лич- } \\
\text { ного про- } \\
\text { фессиональ- } \\
\text { ного опыта, }\end{array}$ \\
\hline
\end{tabular}




\begin{tabular}{|c|c|c|c|c|c|}
\hline $\begin{array}{l}\text { ники полу- } \\
\text { чают роди- } \\
\text { телей в лице } \\
\text { кураторов- } \\
\text { менторов, } \\
\text { братьев и } \\
\text { сестер в } \\
\text { лице сту- } \\
\text { дентов- } \\
\text { старшекурс- } \\
\text { ников }\end{array}$ & $\begin{array}{l}\text { профес- } \\
\text { сиональ- } \\
\text { ной дея- } \\
\text { тельности, } \\
\text { совер- } \\
\text { шенство- } \\
\text { вание об- } \\
\text { щих и } \\
\text { формиро- } \\
\text { вание } \\
\text { професси- } \\
\text { ональных } \\
\text { компетен- } \\
\text { ций }\end{array}$ & $\begin{array}{l}\text { первокурс- } \\
\text { ников } \\
\text { находят } \\
\text { младших } \\
\text { братьев } \\
\text { и сестер, } \\
\text { возмож- } \\
\text { ность де- } \\
\text { литься сво- } \\
\text { им опытом } \\
\text { адаптации }\end{array}$ & $\begin{array}{l}\text { должно } \\
\text { помочь в } \\
\text { развитии } \\
\text { его пре- } \\
\text { подава- } \\
\text { тельской } \\
\text { карьеры, } \\
\text { повыше- } \\
\text { нию ква- } \\
\text { лификации, } \\
\text { росту до- } \\
\text { верия со } \\
\text { стороны } \\
\text { коллектива }\end{array}$ & $\begin{array}{l}\text { навыки } \\
\text { управления, } \\
\text { си- } \\
\text { стематизи- } \\
\text { рует имею- } \\
\text { щиеся зна- } \\
\text { ния и опыт }\end{array}$ & $\begin{array}{l}\text { возможность } \\
\text { установить со } \\
\text { студентом дли- } \\
\text { тельные отно- } \\
\text { шения, приоб- } \\
\text { щение к кор- } \\
\text { поративной } \\
\text { культуре пред- } \\
\text { приятия }\end{array}$ \\
\hline $\begin{array}{l}\text { Развитие у } \\
\text { студентов } \\
\text { положи- } \\
\text { тельного } \\
\text { отношения } \\
\text { к универси- } \\
\text { тету, его } \\
\text { профессор- } \\
\text { ско- } \\
\text { препода- } \\
\text { вательскому } \\
\text { составу, } \\
\text { направле- } \\
\text { нию обуче- } \\
\text { ния }\end{array}$ & $\begin{array}{l}\text { Получение } \\
\text { консуль- } \\
\text { тации и } \\
\text { помощи в } \\
\text { выборе } \\
\text { предприя- } \\
\text { тия, тру- } \\
\text { доустрой- } \\
\text { стве, раз- } \\
\text { работке } \\
\text { бизнес- } \\
\text { проекта и } \\
\text { открытии } \\
\text { собствен- } \\
\text { ного дела }\end{array}$ & $\begin{array}{l}\text { Возмож- } \\
\text { ность по- } \\
\text { красоваться } \\
\text { перед пер- } \\
\text { вокурсни- } \\
\text { ками, найти } \\
\text { единомыш- } \\
\text { ленников, } \\
\text { послушных } \\
\text { последова- } \\
\text { телей своих } \\
\text { идей }\end{array}$ & $\begin{array}{l}\text { Приобре- } \\
\text { тает спо- } \\
\text { собность } \\
\text { принимать } \\
\text { решения, } \\
\text { касающие- } \\
\text { ся людей, } \\
\text { выстраи- } \\
\text { вать отно- } \\
\text { шения, } \\
\text { эффектив- } \\
\text { ные ком- } \\
\text { муникации }\end{array}$ & $\begin{array}{l}\text { Соблюдение } \\
\text { высоких } \\
\text { этических } \\
\text { стандартов, } \\
\text { отвествен- } \\
\text { ность за } \\
\text { наставляе- } \\
\text { мых, их биз- } \\
\text { нес-проект, } \\
\text { трудо- } \\
\text { устройство }\end{array}$ & $\begin{array}{l}\text { Получение но- } \\
\text { вых знаний, } \\
\text { создание ре- } \\
\text { зерва высо- } \\
\text { классных спе- } \\
\text { циалистов, ру- } \\
\text { ководителей и } \\
\text { предпринима- } \\
\text { телей }\end{array}$ \\
\hline $\begin{array}{l}\text { Наставляемый } \\
\text { стратегию } \\
\text { роста, обра } \\
\text { результаты, м } \\
\text { интегрирован } \\
\text { студенческое } \\
\text { затем в прс } \\
\text { ную среду }\end{array}$ & $\begin{array}{r}\text { получает } \\
\text { ичностного } \\
\text { овательные } \\
\text { тивирован, } \\
\text { вначале в } \\
\text { ообщество, } \\
\text { 1зводствен- }\end{array}$ & \multicolumn{4}{|c|}{$\begin{array}{l}\text { Получение огромного удовольствия от общения с молоды- } \\
\text { ми людьми, студентами, от прогрессирующей результатив- } \\
\text { ности учебы и работы своих наставляемых. Создание соб- } \\
\text { ственного сообщества благодарных учеников (менти), со- } \\
\text { вершенствование своих коммуникативных навыков и мене- } \\
\text { джерских способностей }\end{array}$} \\
\hline
\end{tabular}

В России, точнее в СССР, много внимания уделялось развитию наставничества во второй половине XX в., в особенности в профессионально-техническом и производственном обучении. Главной задачей наставничества того времени являлось обучение молодого работника навыкам и умениям со стороны старшего по возрасту коллеги с профессиональным опытом. В системе высшего образования советского периода наставничеству уделялось гораздо меньше внимания.

В последние годы в вузах России под понятием «наставничество» понимается не только тьютерство, но и кураторство, коучинг, работа студенческого самоуправления и др. Наставничество в стране становится все более популярным и востребованным, это подтверждается многочисленными исследованиями. Более 
А. Н. Макаров, В. С. Потаев, Г. Ю. Субанаков. Исследование закономерностей и условий функционирования и развития наставничества в региональной системе образования

того, ранее указом Президента РФ от 3 марта 2018 г. № 94 был учрежден знак отличия «За наставничество». За заслуги в профессиональном становлении молодых специалистов и активную наставническую деятельность этим знаком награждены уже два наставника из сферы высшего образования: Н. Г. Варухин (директор учреждения дополнительного образования), Г. П. Котельников и А. А. Шалыто (главный научный сотрудник Санкт-Петербургского национального университета информационных технологий, механики и оптики).

\section{Литература}

1. Джиоева Ф. А. Формирование механизма наставничества для молодых специалистов в нефтегазовых компаниях: диссертация на соискание ученой степени кандидата экономических наук. Москва, 2014. 201 с. Текст: непосредственный.

2. Масалимова А. Р. Содержание и технологии корпоративной подготовки наставников: педагогическая составляющая: учебно-методическое пособие. Казань: Изд-во КФУ, 2015. 123 с. Текст: непосредственный.

3. Потаев В. С. Об особенностях развития предпринимательских способностей у студентов // Вестник Бурятского государственного университета. Экономика и менеджмент. 2020. № 2. С. 15-23. Текст: непосредственный.

4. Цыренов Д. Д. Оценка когнитивного потенциала студентов университета в условиях становления и развития экономики знаний // Вестник Бурятского государственного университета. Экономика и менеджмент. 2015. № 1. С. 52-58. Текст: непосредственный.

5. Цыренов Д. Д., Эрдыниев Ж. Ч., Адушинов В. Г. Совершенствование системы поддержки малого предпринимательства с использованием аппарата теории игр // Вестник Бурятского государственного университета. Экономика и менеджмент. 2019. № 1. С. 54-61. Текст: непосредственный.

6. Clutterbuck D. Everyone Needs a Mentor. London, 1991. 96 p.

Статья поступила в редакциию 19.04.2021; одобрена после рецензирования 28.04.2021; принята к публикации 28.04.2021.

\section{A STUDY OF REGULARITIES AND CONDITIONS OF MENTORSHIP FUNCTIONING AND DEVELOPMENT IN THE REGIONAL EDUCATION SYSTEM}

Aleksandr N. Makarov

Cand. Sci. (Phys. and Math.), A/Prof.

an-makarov2008@yandex.ru

Viktor S. Potaev

Dr. Sci. (Econ.), Prof.

potaev_viktor@mail.ru

Georgiy Yu. Subanakov

Cand. Sci. (Econ.)

subgeorge@mail.ru

Dorzhi Banzarov Buryat State University

24a Smolina St., Ulan-Ude 670000, Russia

Abstract. The article describes special aspects and effectiveness of introducing mentorship in higher education. Based on the analysis of educational, methodological and scientific 
work in Buryat State University, we have developed the procedure and scheme for introducing a mentoring system. This system involves several forms of mentorship: mentor-curator, mentor-scientific supervisor, mentor-student (senior student), mentor-practitioner. Consequently, the following models of mentoring are proposed: 1) from school to university, 2) from university to production, 3) from production to career. It is expected that mentorship will improve student attendance, their current academic performance, presentation of graduate qualification works and employment. Mentorship can help to partially or completely overcome such problems of modern higher education as low motivation to study and selfdevelopment, disciplinary difficulties, unsatisfactory academic performance, lack of highquality self-regulation among students, low awareness of career and educational opportunities, lack of conscious choice of future career, difficulties associated with the inability to combine work with the study, low general culture level, underdevelopment of metacompetencies.

Keywords: mentorship, special aspects, higher education, competencies, soft skills, curators, mentors, efficiency

\section{For citation}

Makarov A. N., Potaev V. S., Subanakov G. Yu. A Study of Regularities and Conditions of Mentorship Functioning and Development in the Regional Education System. Bulletin of Buryat State University. Economy and Management. 2021; 2: 43-54 (In Russ.).

The article was submitted 19.04.2021; approved after reviewing 28.04.2021; accepted for publication 28.04.2021. 